\title{
Information technology capability and firm performance in the era of Big Data analytics: Evidence from the United States
}

\author{
Md. Jahidur Rahman ${ }^{\mathrm{a} 1}$ and Ning Zhao ${ }^{\mathrm{a}}$ \\ ${ }^{a}$ Wenzhou-Kean University
}

\begin{abstract}
Research Question: This study investigates the relationship between information technology (IT) capability and firm performance in the 2010 s, the era of big data analytics (BDA), in the context of US companies.

Motivation: With the evolution of business intelligence and the proliferation of analytic tools that further improve IT capability, it is more important than ever to understand whether firms with stronger IT capabilities perform better.

Idea: After categorizing firms into pairs of IT leaders and control groups, the performance of each pair of firms in each group was compared.

Data: All data are publicly available from Compustat and InformationWeek (IW) 500.

Tools: The Wilcoxon signed-rank test and regression analysis were used to examine how the performance of IT leaders and control groups changed during the 2010-2017 period.

Findings: This results show no significant relationship between a firm's IT capability and its performance in the sample of US companies during this period.

Contribution: This study will help academicians and practitioners to better understand how the adoption and application of BDA derived from IT capability affects firm performance.
\end{abstract}

Keywords: Big data analytics (BDA), information technology (IT) capability, firm performance, IW 500, IT business value

JEL codes: M41, L25

\footnotetext{
${ }^{1}$ Corresponding authors: Department of Accounting, Wenzhou-Kean University, 88 Daxue Road, Ouhai, Wenzhou, Zhejiang Province, China 325060; Tel: (0577) 55870479; email addresses: mdjahidr@kean.edu; zhaon@kean.edu
} 


\section{Introduction}

Understanding how a firm's information technology (IT) capability affects its business performance has been controversial since the 1990s, and a wealth of literature on the value of IT in business has been developed since then (Chan, 2000; Dehning \& Richardson, 2002; Kohli \& Devaraj, 2003; Mahmood \& Mann, 2000; Melville et al., 2004; Wade \& Hulland, 2004). Despite the doubts over IT's direct influence on firm performance (Carr, 2003; Clemons, 1986, 1991; Clemons \& Row, 1991; Powell \& Dent-Micallef, 1997), information systems (IS) researchers agree that a firm with superior IT capabilities has a huge competitive edge (Chae et al., 2014). However, the IT capability-firm performance relationship is mixed (Mata et al., 1995; Ray et al., 2005). The IS community acknowledges that a firm's superior IT capabilities do not necessarily improve its performance per se, but can serve as a catalyst for higher-order organizational capabilities and improved firm performance (Ales et al., 2016).

Whereas the 1990s were characterized by proprietary information systems, the 2000s were mainly governed by standardized and identical information systems, thanks to the rapid adoption of enterprise resource planning (ERP) and web technologies (Wang, 2010). Therefore, some studies have investigated the relationship between a firm's IT capability and its performance during different time periods. Bharadwaj (2000), for instance, has been cited 5, 141 times according to the data from Google Scholar, and is one of the most convincing studies that provides strong evidence for the link between IT capability and firm performance. This study claims that firms with superior IT capabilities performed better in business than their counterparts during 1991-1994. Using the resource-based view (RBV), it argues that firms categorized as IT leaders can make use of IT-related resources to produce unique IT capabilities that can lead to superior business performance and consequently, become the basis for their future competitive edge. Santhanam and Hartono (2003), an extension of Bharadwaj (2000), confirm that the performance of IT leaders is superior to that of corresponding paired firms in the control group (firms that match IT leader firms in terms of industry and size). Their study also finds that a firm's competitive advantage generated through its IT capability can be sustained. Following the widespread changes in IT and the way in which organizations leverage IT, another study, that of Chae et al. (2014) updates the above studies with fresh data from the early 2000s. Contrary to the previous findings, this study failed to find a link between IT leaders and superior business performance, as measured by profit and cost ratios, irrespective of whether this relationship is assessed by the industry-benchmark test, the pair-wise comparison test, or by regression analysis. Moreover, there is no evidence to support the sustainability of IT capability. 
The IT business value literature has continued to stress the potential and the ability of information systems to assist in decision making and enhance company performance (Davern \& Kauffman, 2000; Mithas et al., 2011; Melville et al., 2004; Bhattacharya et al., 2010). The capacity of IS to help a firm make timely decisions, generate insights that elevate a firm's comparative advantage, and serve as a tool to deal with environmental uncertainties has been acknowledged in firm performance research (Popovič et al., 2014). As a result, firms depend on IS to obtain high-quality information that is relevant, reliable, accurate and timely (Popovič et al., 2012; Wixom \& Todd, 2005), which improves the quality of their decision making and boosts their business performance (Mithas et al., 2011). Using this insightful information, firms are increasingly investing in a variety of technologies and incorporating them into their business activities and processes (Chen et al., 2012).

However, over the years, business intelligence and analytics and big data analytics (BDA) have become increasingly important in both business and academic circles (Chen et al., 2012). The changes and transformation in business and society have been partly brought about by big data (Marr, 2016). From the academic community's perspective, BDA research has grabbed the attention of widely read scientific outlets, such as Science and the Proceedings of the National Academy of Sciences, because of its nature and significance (Agarwal \& Dhar, 2014). Moreover, firms are constantly attempting to generate insights from the expanding value, variety, veracity, velocity, and volume of data to better utilize data and improve decision making (Lavalle et al., 2011; White, 2012). In addition to using data to solve known issues, firms are using data to uncover trends that they failed to notice earlier (Fosso Wamba et al., 2015). The tremendous opportunities associated with data, information, and analysis in various organizations have aroused keen interest in BDA, which is commonly recognized as the technologies, systems, techniques, methodologies, practices, and applications that analyze various critical business data to enable firms to better assess their business and markets, and to make timely and efficient business decisions (Gandomi \& Haider, 2015; Mcafee \& Brynjolfsson, 2012). BDA mainly derives from a firm's IT-based resources such as physical IT infrastructure, human IT resources, and intangible resources (Agrawal, 2013; Grant, 1991). IT capability is predominantly defined as a firm's capability to mobilize, deploy, and use its IT-based resources to enhance its business performance (Santhanam \& Hartono, 2003), which plays a significantly positive role in BDA adoption and application.

Therefore, in this study we investigate the link between a firm's IT capability and its business performance in the 2010s (the BDA era) in US companies during 2010-2017. The timeframe begins with 2010 for the following two reasons. First, the number of academic publications that focused on BDA increased exponentially from 2010 and their focus was on big data-enabled business value, that is, to store, compute, analyze, visualize, and integrate the growing quantity of data from various sources and transform these data into business insights and value. (McAfee \& 
Brynjolfsson, 2012; Wamba et al., 2015). Second, this study serves as an extension of the previous studies that deployed data from 1990 through 1997 (Bharadwaj, 2000; Santhanam \& Hartono, 2003) and 2000 to 2007 (Chae et al., 2014) to reexamine the relationship between a firm's IT capability and its business performance. We use US-listed companies as our sample for several reasons. While BDA has both direct and indirect impacts on the financial performance of companies in China (Wamba et al., 2017), its impact on the financial performance of companies in the US has not been investigated. As an ongoing study that aims to make a direct and valid comparison with the previous studies mentioned above, we choose US-listed firms for consistency. Moreover, as unlisted companies' relevant financial data are difficult to obtain and listed companies' financial data are publicly available, we select only listed companies in the United States as our sample.

Our hypotheses state that IT leaders are associated with superior business performance and sustained superior business performance compared with the control groups, both before and after adjusting for the impacts from previous years' financial performance through the following years' financial performance. Based on a sample of 55 sets of IT leaders and control groups selected from IW 500 and their financial data from 2010 through 2017, this study finds that although IT leaders showed and sustained higher profit ratios than the control groups before the financial halo effects adjustment, such a correlation no longer existed after the adjustment.

This study makes two contributions to the literature on the business value of IT. First, it determines the relationship between a firm's IT capability and its business performance by adding a new construct, which is the influence of BDA since the 2010s. BDA-supported decision making enables decision makers to use robust and timely data to enhance the effectiveness of business decisions, which leads to better business performance. Second, it updates past studies with fresh data from the 2010s. Past studies use data from the early 1990s and 2000s to investigate the relationship between a firm's IT capability and its business performance, and therefore, their findings may not be relevant after a decade of rapid change in the use of technology in business, especially BDA. Replications and updates are vital in the scientific community because they examine the robustness of theories and fortify experimental beliefs into agreed knowledge (Santhanam \& Hartono, 2003). However, researchers often do not make full use of replicative studies to reexamine what has been scientifically explored (Berthon et al., 2002).

The remainder of this paper is organized as follows. Section 2 reviews the relevant literature and proposes the corresponding hypotheses. Section 3 outlines the research approach, data sources, and data analysis procedures. Section 4 presents the main findings of the research. Section 5 describes some possible explanations and unavoidable limitations of this study, and offers some avenues for future research. 


\section{Past research and development of hypotheses}

\subsection{IT capability and firm performance}

IT capability is largely defined as a firm's capability to mobilize, deploy, and use IT-based resources to enhance its business performance (Santhanam \& Hartono, 2003). According to Porter (2011), firms can increase their business performance by utilizing their IT capabilities to reduce costs, increase revenues, or both. First, firms with superior IT capabilities can increase product differentiation by leveraging web technologies to generate higher sales (Hitt \& Brynjolfsson, 1996). For example, some banks have launched financial services that rely on websites to differentiate their products and services based on customers' profiles. In addition, firms with superior IT capabilities can (1) improve their sales performance by generating valuable resources such as patents and other intellectual property (Fahy \& Hooley, 2002); (2) significantly reduce their marketing costs by increasing switching costs and improving customer loyalty (Davenport, 2006); (3) gain exclusive access to customers' information and personal preferences, which can potentially save future business research costs (Straub \& Watson, 2001). This proprietary information could save firms wanting to expand their business to new markets from incurring heavy expenditure.

Grant (1991) classified IT-based resources into three categories: tangible resources consisting of the physical IT infrastructure elements, human IT resources with managerial and technical IT skills, and intangible IT-enabled resources such as knowledge assets, customer orientation, and synergy.

According to the RBV, firms can innovate swiftly and improve their products by using tangible resources (Bharadwaj, 2000). Compared with a firm with a disaggregated and less developed IT infrastructure, a firm with an integrated IT infrastructure can launch innovative IT applications quicker than its competitors (Bharadwaj, 2000). Therefore, tangible resources play a significant role in the BDA adoption process.

Human resources have technical IT skills and managerial skills. As BDA adoption entails significant changes in business processes and IT infrastructure, managerial capability plays a significant role in coordinating activities pertaining to process redesign (Zhu et al., 2006).

Intangible resources consist of customer orientation, knowledge assets, and synergy (Bharadwaj, 2000). Past studies have indicated that customer orientation plays a significant role in innovation adoption (Agrawal, 2013). "Knowledge assets" refer to the integration of intellectual resources, namely, employees' knowledge, skills, and experiences into an organization's processes, policies, and information repositories 
(Bharadwaj, 2000). Knowledge assets also play a critical role in BDA adoption because if employees' knowledge and skills are well developed, they are more likely to assimilate new innovations. Synergy is the organization-wide pooling of resources and capabilities to achieve a combined result that is superior to its individual components (Bharadwaj, 2000). Firms that are able to share information and knowledge across different functional and business units are more agile and respond faster to situations. As BDA is empowered to share information across all key functions such as R\&D, purchasing, production, warehousing, and marketing, it paves the way for sharing information and resources (Agrawal, 2013). Therefore, the synergy from intangible resources is positively related to BDA adoption and application. Based on the discussion mentioned above, for a firm to demonstrate IT capability, BDA adoption should be significantly and positively related to physical IT infrastructure, human IT resources, and intangible resources.

The above discussion is an example of how IT capability influences a firm's business performance in the era of the Internet and BDA. Specifically, the business value of $\mathrm{BDA}$, which is reflected in business performance, can be defined as the transactional, informational, and strategic benefits derived from BDA and brought to firms (Akter \& Wamba, 2016). For example, the large volume of online consumer reviews generated on shopping platforms enables organizations to analyze and understand different consumers' preferences and behavior, thus enabling the optimization of the organizations' service and sales performance (Salehan \& Kim, 2016). As with any other technology, it is significant for organizations to understand the relevant mechanisms, processes, and results of big data, through which business value is developed and added (Mikalef et al., 2018). Although big data can give rise to various implications and applications in terms of valuation, legal protection, policy, and commercialization for organizations (Iqbal et al., 2020), only the implications that are reflected in organizations' financial performance are discussed in this study. Therefore, the following two hypotheses are formulated wherein financial ratios are leveraged to understand the impacts of BDA.

H1: Firms that had superior IT capabilities in the 2010s are associated with higher average profit ratios than those of control firms.

H2: Firms that had superior IT capabilities in the 2010s are associated with lower average cost ratios than those of control firms.

\subsection{Sustainability of IT capability and business performance}

The important question of whether firms' successful business performance resulting from IT capability can be sustained in the long run has become more difficult to answer. On the one hand, unlike the early stages of IT development that were characterized by proprietary information systems, the modern IT environment 
mainly consists of highly standardized IS applications due to the quick adoption of web technology and ERP, which makes it easier for a firm to counter and even surpass its competitors' IT capabilities. The time and costs involved in developing IS are also significantly reduced, thanks to advancements such as off shoring, readily available web search engines, and outsourcing (Porter, 2001). However, all of the IT-based competitive advantages obtained from these developments are short lived (Carr, 2003).

On the other hand, owing to a large and increasing amount of sensor-generated, mobile, and web-based data being obtained from IS, a vast amount of relevant, contextualized, and detailed content is made available to firms, which guides their short-term and long-term development and which is beneficial for BDA value creation and realization (Agarwal \& Dhar, 2014; Chen et al., 2012; Grover et al., 2018). IT-enabled intangible assets, such as knowledge assets, are likely to enhance technological competence and capabilities, thus influencing firm performance and IT projects (Barney, 1991; Bharadwaj, 2000; Mata et al., 1995; Melville et al., 2004; Santhanam \& Hartono, 2003; Wade \& Hulland, 2004). Strategies that are driven by BDA contribute to business growth with sustained performance, which is also reflected in the internal processes (Singh \& El-Kassar, 2019).

Despite the changing IT environment in which a firm can easily obtain applications and analytical insights (Chae et al., 2014), a firm's IT capability is likely to be linked to sustainable business performance. Therefore, we propose the following two hypotheses:

H3: Firms that had superior IT capabilities in the 2010s are associated with higher average profit ratios than those of control firms in all subsequent years.

H4: Firms that had superior IT capabilities in the 2010s are associated with lower average cost ratios than those of control firms in all subsequent years.

\subsection{The financial halo effect}

Past studies have found that the results of popular industry rankings, for instance Fortune's Most Admired Companies, can be greatly affected by past financial performance, and the influence of past financial performance on a reputation survey is defined as a financial halo effect (Brown \& Perry, 1994). A previous study (Bharadwaj, 2000) used a method whereby a firm is selected as an IT leader on the basis of its IT capability rather than its previous financial performance, and that there is no evidence of a financial halo effect. It is very important to ensure that a firm is recognized as an IT leader because of its superior IT capability and not because of its previous financial performance (Chae et al., 2014). Otherwise, the reliability and 
validity of business performance comparisons between IT leaders and control groups becomes questionable.

A follow-up study (Santhanam \& Hartono, 2003) further investigated the financial halo effect. They argued that use of the financial halo effect in Bharadwaj (2000) to select IT leaders may not be sufficient, as the researcher made use of a firm's previous five years' financial performance despite the fact that the firm's ranking was affected most by its immediate past performance. Therefore, they claimed that the influence of IT capability should be reexamined via a more conservative and rigorous method by adjusting for a firm's past financial performance. Their concerns were legitimate, because the much better performance of the IT leaders than the control groups in the pair-wise comparison test was significantly weak when firms' previous financial performance was adjusted for.

In line with Santhanam and Hartono (2003), Chae et al., (2014) also used a method to ensure that IT leaders' capabilities, rather than their past financial performance, differentiates them from control companies. Consistent with their research, a firm's previous year performance has a huge impact on its current year performance.

Similar to Santhanam and Hartono's (2003) approach, this study also seeks to ascertain that IT capability, and not previous financial performance, differentiates IT leaders from control companies. Consequently, additional tests controlling the effects of previous financial performance on the results should be performed. The following hypotheses are therefore proposed:

H5: Firms that had superior IT capabilities in the 2010s are associated with higher average profit ratios than those of control firms after adjustment for prior financial performance.

H6: Firms that had superior IT capabilities in the 2010s are associated with lower average cost ratios than those of control firms after adjustment for prior financial performance.

H7: After adjustment for previous financial performance, firms that had superior IT capabilities in the 2010s are associated with higher average profit ratios than those of control firms in the subsequent years.

H8: After adjustment for previous financial performance, firms that had superior IT capabilities in the 2010s are associated with lower average cost ratios than those of control firms in the subsequent years.

As this study was conducted after those of Bharadwaj (2000), Santhanam and Hartono (2003), and Chae (2014), and their research methodologies are heavily referenced, a comparison between those studies is presented in Table 1. 
Table 1. Comparison between earlier studies and current study

\begin{tabular}{|c|c|c|c|}
\hline Studies & Sample & $\begin{array}{l}\text { Benchmark } \\
\text { (Control Group) }\end{array}$ & Measures \\
\hline $\begin{array}{l}\text { Bharadwaj } \\
(2000)\end{array}$ & $\begin{array}{l}\text { IT leaders from } \\
1991-1994 \text { IW } \\
500 \text { listings }\end{array}$ & $\begin{array}{l}\text { IT leader versus } \\
\text { control company of } \\
\text { similar size and } \\
\text { industry }\end{array}$ & $\begin{array}{l}\text { Business performance measured } \\
\text { by profit and cost ratios from } 1991 \\
\text { to } 1994 \text {. }\end{array}$ \\
\hline $\begin{array}{l}\text { Santhanam } \\
\text { and Hartono } \\
\quad(2003)\end{array}$ & $\begin{array}{l}\text { IT leaders from } \\
1991-1994 \text { IW } \\
500 \text { listings }\end{array}$ & $\begin{array}{l}\text { IT leaders versus } \\
\text { industry average }\end{array}$ & $\begin{array}{l}\text { Business performance measured } \\
\text { by profit and cost ratios from } 1991 \\
\text { to } 19942 \text {. Sustainability of } \\
\text { superior business performance } \\
\text { from } 1995 \text { to } 1997 \text {. }\end{array}$ \\
\hline $\begin{array}{l}\text { Chae et al. } \\
\text { (2014) }\end{array}$ & $\begin{array}{l}\text { IT leaders } \\
\text { selected from } \\
2001-2004 \text { IW } \\
500\end{array}$ & $\begin{array}{l}\text { IT leaders versus } \\
\text { control companies } \\
\text { of similar size and } \\
\text { industry }\end{array}$ & $\begin{array}{l}\text { Business performance measured } \\
\text { by profit and cost ratios from } 2001 \\
\text { to } 20042 \text {. Sustainability of } \\
\text { superior business performance } \\
\text { from } 2005 \text { to } 2007 \text {. }\end{array}$ \\
\hline This study & $\begin{array}{l}\text { IT leaders } \\
\text { selected from }\end{array}$ & $\begin{array}{l}\text { IT leaders versus } \\
\text { control companies }\end{array}$ & $\begin{array}{l}\text { Business performance measured } \\
\text { by profit and cost ratios from } 2010\end{array}$ \\
\hline $\begin{array}{l}\text { Rahman and } \\
\text { Zhao (2020) }\end{array}$ & $\begin{array}{l}2010-2013 \mathrm{IW} \\
500\end{array}$ & $\begin{array}{l}\text { of similar size and } \\
\text { industry }\end{array}$ & $\begin{array}{l}\text { to } 20132 \text {. Sustainability of } \\
\text { superior business performance } \\
\text { from } 2014 \text { to } 2016 \text {. }\end{array}$ \\
\hline
\end{tabular}

\section{Methods and data collection}

Bharadwaj's (2000) "matched sample comparison group" is used in this study to test the formulated hypotheses empirically. This technique selects a treatment sample and a control sample, and then compares the interest variables' levels between these two groups. The treatment sample consists of IT leaders with superior IT capabilities and the control sample consists of firms that match the control sample in terms of industry and size. Next, the IT leaders' performance measurement results are compared with those of the control group.

\subsection{Data collection}

IS researchers have been using IW 500 for years to identify IT leaders with superior IT capabilities. Since 1989, IW 500 has selected and recognized 500 companies as annual leaders in business technology innovation. Its criteria for choosing IT leaders have evolved to better reflect ever-changing business and technology advancements and the refinement of its benchmarking power. Despite the frequent changes in its selection criteria, IW 500 continues to be recognized as a reliable indicator of firms' IT capabilities and has been cited in previous studies (Bharadwaj, 2000; Hitt \& Brynjolfsson, 1996; Chae et al., 2014; Santhanam \& Hartono, 2003; Stoel \& 
Muhanna, 2009). Firms with superior IT capabilities are those recognized by IW 500 during 2010-2013. To ensure the selection of firms with sustainable IT capabilities, the IT leader sample was limited to firms that were listed in IW 500 for at least two years during those four years.

The matching control firms were selected on the basis of sales levels - those that had the closest five-year average sales to the IT leaders were chosen. In line with Bharadwaj (2000), the control firms' average sales should be between $70 \%$ and $130 \%$ of those of the leader firms. Essentially, the control firm should be from the same industry as the IT leader, and its average sales from 2005 through 2009 should be between $70 \%$ and $130 \%$ of the leader's average sales during the same period. Table 2 summarizes the sample selection in a systematic manner.

Table 2. Sample selection methods

\begin{tabular}{rlr}
\hline Step & Procedure & \multicolumn{2}{c}{$\begin{array}{l}\text { Number } \\
\text { of Companies }\end{array}$} \\
\hline 1 & Identify companies listed in the IW 500 from 2010 to 2013. & 2,000 \\
2 & $\begin{array}{l}\text { Restrict the IT leader sample to those that were listed at least } \\
\text { twice in the IW 500 from 2010 to 2013. }\end{array}$ \\
3 & Select IT leaders with comparable companies. & 569 \\
\hline
\end{tabular}

It is critical to choose a control firm from the same industry as the IT leader and ensure that it is of the same size as the IT leader for the following reasons. First, operating performance differs considerably across different industries and firm sizes. Differences in performance caused by the variance in industry and firm size are significantly reduced by using matching samples (Chae et al., 2014). Moreover, according to the accounting literature, industry type and firm size are widely used by accounting methods such as amortization and depreciation, in the calculation of costs (Bharadwaj, 2000). Therefore, effective control of the effects of variance from accounting methods leads to are liable comparison between profitability and cost ratios.

We selected a single control firm (benchmark) for each IT leader firm and did not consider all of the other firms in that industry for comparison (Chae et al., 2014) for the following reasons. Unlike the studies conducted by Bharadwaj (2000) and Santhanam and Hartono (2003) that used only 56 leader and control pairs, this study uses 276 groups of samples. Therefore, it may not be appropriate to incorporate all firms in an industry to calculate the benchmark that is arrived at with a single set of benchmark firm data (Chae et al., 2014). As a result, each IT leader firm is paired 
with a control group using the above methods. As Table 3 indicates, firms categorized as IT leaders are large, with total assets of US\$24.4 billion and average sales of US\$7.5 billion. This research shows that an IT leader is almost twice as large as the average firm in its respective industry. As discussed earlier, a firm's size directly influences its IT budget and resources, and IT leaders could have greater IT resources than other firms in the industry.

Table 3. Comparison between the IT leader group and the control group

\begin{tabular}{|c|c|c|c|c|}
\hline \multirow{2}{*}{ Descriptive Variables } & \multicolumn{2}{|c|}{ IT Leader Sample } & \multicolumn{2}{|c|}{ Control Sample } \\
\hline & Mean & Median & Mean & Median \\
\hline Sales (billion \$) & 7.512 & 1.489 & 4.315 & 1.943 \\
\hline Assets (billion \$) & 24.398 & 2.145 & 12.826 & 2.596 \\
\hline Number of Employees (thousand) & 20.173 & 5.364 & 16.252 & 6.386 \\
\hline
\end{tabular}

The variables chosen in this study to reflect business performance are the same as those in Bharadwaj (2000). Superior business performance is defined by profit and cost performance parameters such as higher profit ratios and lower cost ratios. Specifically, the profit ratios category, which incorporates the measurement of firm size based on sales performance, assets value, expenses, and the number of employees, includes the following.

1) Return on assets (ROA). ROA has been widely adopted in the IT business value literature to measure a firm's profitability and is correlated with other profitability measures (Kanodia et al., 2016).

2) Return on sales (ROS). ROS is also widely used in the IT business value literature as an indicator of the net profit margin of a firm (Kanodia et al., 2016).

3) Operating income to assets (OI/A)

4) Operating income to sales $(\mathrm{OI} / \mathrm{S})$. As the operating income excludes revenue streams from other sources such as interest income, the measurement of $\mathrm{OI} / \mathrm{A}$ and $\mathrm{OI} / \mathrm{S}$ are appropriate to indicate the business value of IT.

5) Operating income to employees (OI/E). As Bharadwaj (2000) did not clearly define operating income and earnings before interest payment, the earnings before interest and taxes (EBIT) is used as the operating income in this study. This ratio is used to measure the relative profitability of effective IT users.

The cost ratios category is detailed below:

1) Total operating expenses to sales (OPEXP/S). Total operating expenses is selected because it is recognized as the most universal and comprehensive measure of the cost of a firm's operations (Enache et al., 2018).

2) Cost of goods sold to sales $(\mathrm{COG} / \mathrm{S})$ and 
3) Selling and general administrative expenses to sales (SGA/S). Both the cost of goods sold and the general administrative expenses are widely accepted in accounting as measures of the costs related to production and overheads (Bharadwaj, 2000). Operating expenses are computed as the sum of SGA and COG, in line with Bharadwaj (2000).

It is widely accepted that the consistent application of accounting treatment is important in an accounting-related context (Wüstemann et al., 2000). Although the measurement of the above ratios is subject to changes due to modifications in the accounting treatment from time to time, these changes tend to improve the reliability and accuracy of accounts (Chulle et al., 2015). Therefore, the comparison of the ratios during different years focuses more on what the relative accounts stand for than on how the accounts are calculated.

The Compustat database was the source of financial data. The data were used to determine whether IT leaders have lower costs and higher profits than their corresponding control firms during 2010-2013.

The sustainability of superior business performance was assessed by whether IT leaders hold a higher profit and lower cost over time. Both the IT leaders' and control firms' profit and cost ratios were analyzed for the 2014-2017 period. The constructs and corresponding measurements that were used are summarized in Table 4.

However, after extracting all IT leaders and control groups' financial data from Compustat's database, only 56 sets of IT leaders and control groups remained valid for subsequent research because of the following reasons. Not all of the companies selected by IW 500 were listed companies, and the financial data of unlisted companies were not available on Compustat. As a result, 13 sets of groups were eliminated. In addition, because this study requires consecutive data from 2010 through 2017, any variable missing in any year makes this group invalid. Most of the missing values were those of employee numbers and selling and general administrative expenses. As a result, only 56 sets of groups that contained IT leaders and control groups were retained.

Table 4. Summary of constructs and measurement

\begin{tabular}{|c|c|c|c|c|}
\hline Category & Constructs & Definition & Measurement & Sources \\
\hline $\begin{array}{l}\text { Independent } \\
\text { variable }\end{array}$ & IT Capability & $\begin{array}{l}\text { A firm's ability } \\
\text { to assemble, } \\
\text { integrate and } \\
\text { deploy IT- } \\
\text { based resources. }\end{array}$ & $\begin{array}{l}\text { The firms ranked } \\
\text { Information Week } \\
500 \text { more than twice } \\
\text { from } 2010 \text { to } 2013\end{array}$ & $\begin{array}{l}\text { Bharadwaj } \\
\text { (2000); Rai et } \\
\text { al. }(1997)\end{array}$ \\
\hline $\begin{array}{c}\text { Dependent } \\
\text { variables }\end{array}$ & $\begin{array}{c}\text { Superior } \\
\text { Business } \\
\text { Performance }\end{array}$ & $\begin{array}{l}\text { Higher profit } \\
\text { and lower cost } \\
\text { than the control }\end{array}$ & $\begin{array}{l}\text { ROA, ROS, OI/A, } \\
\text { OI/S, OI/E, COG/S, } \\
\text { SGA/S, OPEXP/S }\end{array}$ & $\begin{array}{c}\text { Bharadwaj } \\
\text { (2000); Porter } \\
(1985)\end{array}$ \\
\hline
\end{tabular}




\begin{tabular}{clllc}
\hline Category & Constructs & \multicolumn{1}{c}{ Definition } & \multicolumn{1}{c}{ Measurement } & Sources \\
\hline & group. & from 2010 to 2013 & \\
& Sustained & Sustained & ROA, ROS, OI/A, & Bharadwaj \\
Superior & higher profit & OI/S, OI/E, COG/S, & $(2000) ;$ \\
Business & and lower cost & SGA/S, OPEXP/S & Santhanam \\
& Performance & than the control & from 2014 to 2017 & $\begin{array}{c}\text { and Hartono } \\
\text { group. }\end{array}$ \\
& & & & (2003) \\
\hline
\end{tabular}

\subsection{Statistical tests}

This study investigates whether the firms with higher IT capabilities are likely to show superior financial performance as compared with the matching control firms. Comparing the mean value of variables for the IT leader group with that of the control sample via a standard $t$-test was one of the methods used to test the hypotheses. However, because the sample is not normally distributed, the Wilcoxon signed-rank test, which is a non-parametric test, was used. This test classifies one IT leader firm and a corresponding control firm into one pair and measures the differences between the pairs. By adopting the Wilcoxon signed-rank test, the variance in performance caused by the differences in industry can be effectively removed (Chae et al., 2014).

Consistent with Santhanam and Hartono (2003), the same regression analysis methods for testing hypotheses H5, H6, H7, and H8 were adopted. Each financial performance measurement was conducted by two separate regression analyses as follows. The first analysis investigated how previous performance affects the current year's performance, and therefore, a regression analysis that regresses previous years' performance on current performance was performed. An additional binary variable was used in the second analysis to distinguish IT leaders from control firms ( 1 for IT leaders, and 0 for the control group). The two models are expressed as follows:

$$
\begin{gathered}
\mathrm{FP}_{\mathrm{t}}=\beta_{0}+\beta_{1} \mathrm{FP}(\mathrm{t}-1) \\
\mathrm{FP}_{\mathrm{t}}=\alpha_{0}+\alpha_{1} \mathrm{FP}_{(\mathrm{t}-1)}+\alpha_{2} \mathrm{D}
\end{gathered}
$$

Where,

FP denotes financial performance;

$\mathrm{t}$ denotes the time period; $\mathrm{D}$ denotes the $(0,1)$ binary variable;

$\alpha_{1}, \alpha_{2}$, and $\beta_{1}$ are regression coefficients; and

$\beta_{0}$ and $\alpha_{0}$ are the intercepts.

$\alpha_{2}$, the significance of the coefficient of the dummy variable in the second model, determines whether IT capability has a significant influence on business performance after adjusting for the effects of previous financial performance on current performance. 


\section{Empirical results}

\subsection{Empirical results for superior business performance and sustained superior business performance}

The statistical results of the Wilcoxon signed-rank test from 2010 through 2017 are presented in Tables 5 and 6 . Both the mean and median of the performance measurement are displayed. The statistical test results are reported as $\mathrm{P}$ values and $\mathrm{Z}$ values. H1, which states that the IT leaders have higher profit ratios than those of the control groups, is supported.

The IT leaders group was associated with better performance in terms of profit ratios including ROA, ROS, OI/A, and OI/E for all four years from 2010 through 2013. Notably, the ROA and ROS showed high significance levels from 2011 to 2013. H2, which pertains to cost ratios, holds partially true. IT leaders' OPEXP/S was higher in three of the four years, COG/S was higher in all four years, and only SGA/S was lower in all four years.

The results for $\mathrm{H} 3$ and $\mathrm{H} 4$, which examine whether superior business performance driven by IT capability can be sustained over time, are displayed in Table 6. IT leaders did show higher profit ratios than those of control firms in all four years from 2014 through 2017, and thus hypothesis H3 is fully supported.

In line with H1, the ROA and ROS showed high significance levels from 2014 through 2017. In accordance with the results for H4, IT leaders had a higher COG/S than that of the control group in all four years but experienced lower OPEXP/S and $\mathrm{SGA} / \mathrm{S}$ in all of the four years. Consequently, hypothesis H6 is partially supported.

\subsection{Empirical results for the adjustment of financial halo effects}

To understand how IT capability affects business performance after adjustment for previous years' firm performance, we conducted regression analysis. The results are reported in Table 7. Specifically, the regression coefficients of the models in equations 1 and 2 and changes in R-squares are presented in Table 7.

Consistent with the study's expectation, the previous year's organizational performance had a significant impact on the current year's organizational performance. However, according to the significance of the coefficient of the dummy variable for profit ratios and cost ratios in the second model, only the ROA in 2011 with a positive coefficient was significant at the 5\% level. Therefore, H5, H6, $\mathrm{H} 7$, and $\mathrm{H} 8$ are not supported. The results of the hypotheses tests are summarized in Table 8 . 
Table 5. Results of test on superior business performance

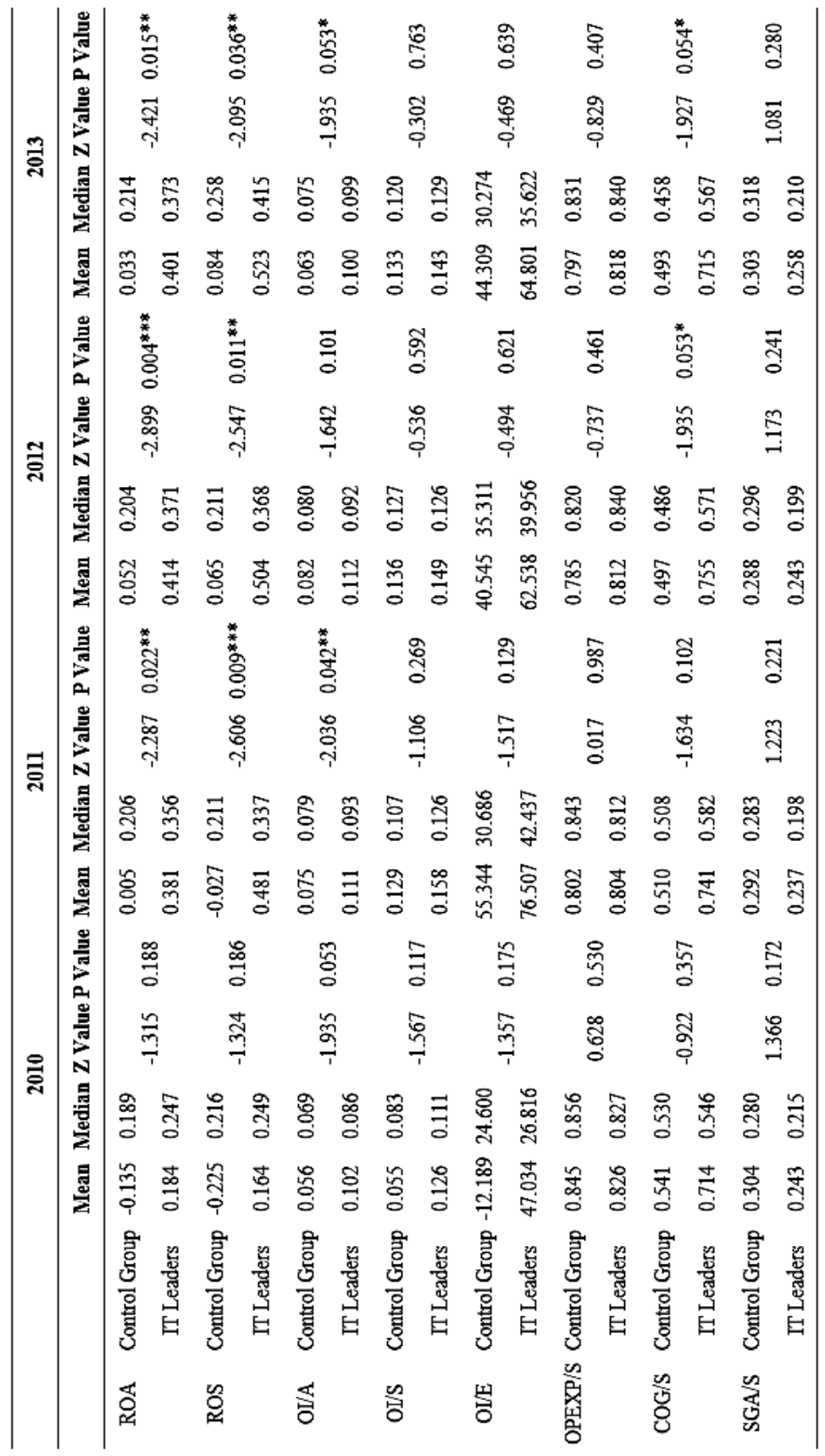


Table 6. Results of test on superior business performance sustainability

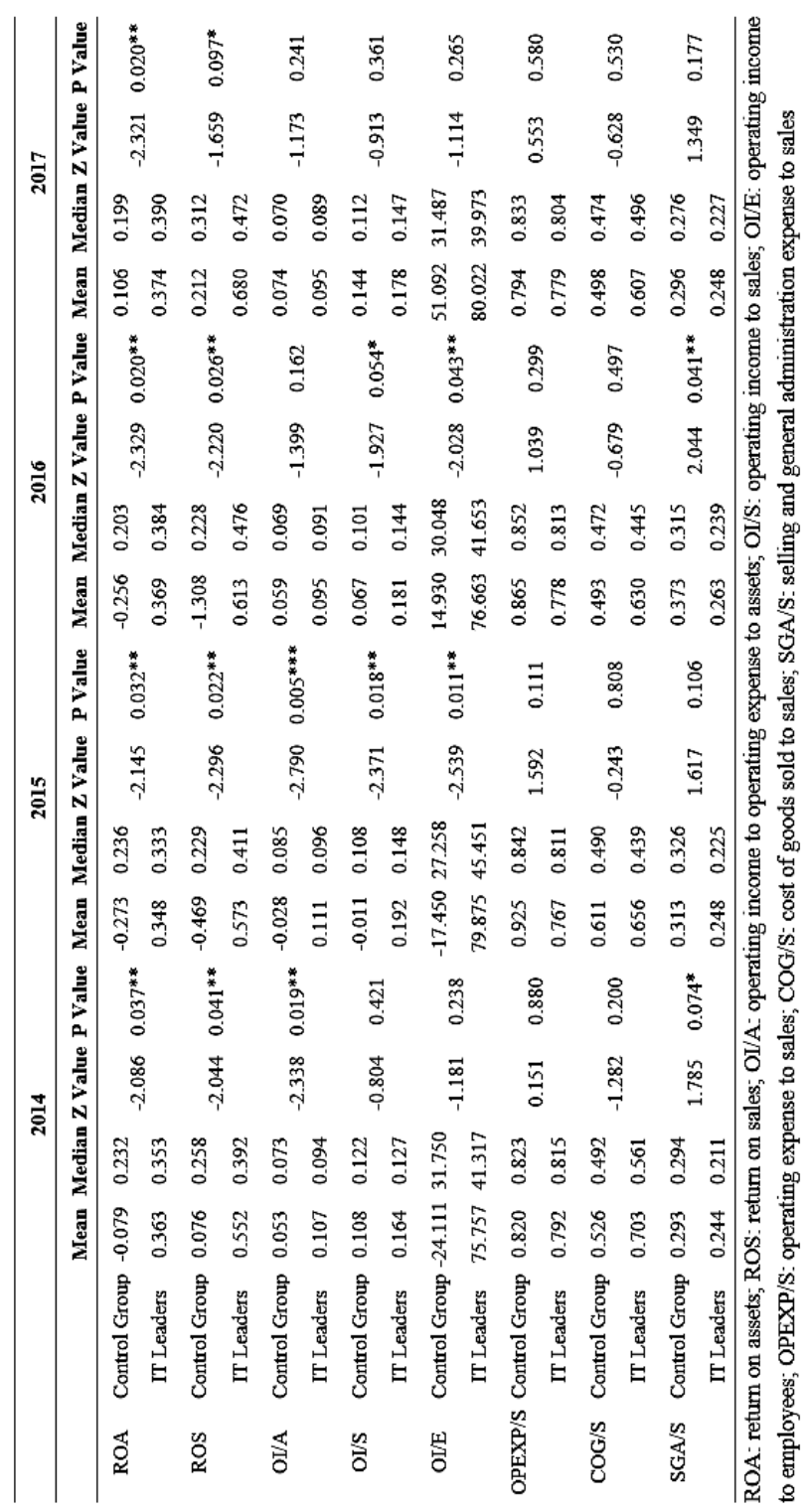


Table 7. Regression analysis

\begin{tabular}{|c|c|c|c|c|}
\hline & Model & $\underline{\text { R Square Change }}$ & $\underline{2010}$ Financial Performance & $\frac{\text { Dummy }}{\text { Variable }}$ \\
\hline \multirow[t]{2}{*}{$\mathrm{ROA}$} & 1 & 0.027 & 0.130 & \\
\hline & 2 & 0.099 & 0.088 & $0.348 * *$ \\
\hline \multirow[t]{2}{*}{ ROS } & 1 & 0.054 & 0.202 & \\
\hline & 2 & 0.120 & 0.157 & 0.448 \\
\hline \multirow[t]{2}{*}{$\mathrm{OI} / \mathrm{A}$} & 1 & 0.017 & 0.116 & \\
\hline & 2 & 0.044 & 0.086 & 0.033 \\
\hline \multirow[t]{2}{*}{$\mathrm{OI} / \mathrm{S}$} & 1 & 0.058 & 0.137 & \\
\hline & 2 & 0.064 & 0.130 & 0.020 \\
\hline \multirow[t]{2}{*}{$\mathrm{OI} / \mathrm{E}$} & 1 & 0.008 & 0.051 & \\
\hline & 2 & 0.013 & 0.046 & 18.431 \\
\hline \multirow[t]{2}{*}{$\mathrm{OPEXP} / \mathrm{S}$} & 1 & 0.008 & 0.087 & \\
\hline & 2 & 0.008 & 0.087 & 0.003 \\
\hline \multirow[t]{2}{*}{$\mathrm{COG} / \mathrm{S}$} & 1 & 0.000 & -0.010 & \\
\hline & 2 & 0.048 & -0.054 & 0.240 \\
\hline \multirow[t]{2}{*}{ SGA/S } & 1 & 0.004 & 0.058 & \\
\hline & 2 & 0.027 & 0.038 & -0.053 \\
\hline \multicolumn{5}{|l|}{2012} \\
\hline & $\underline{\text { Model }}$ & $\underline{\text { R Square Change }}$ & $\underline{2011}$ Financial Performance & $\frac{\text { Dummy }}{\text { Variable }}$ \\
\hline \multirow[t]{2}{*}{$\mathrm{ROA}$} & 1 & 0.093 & 0.284 & \\
\hline & 2 & 0.144 & 0.220 & 0.280 \\
\hline \multirow[t]{2}{*}{ ROS } & 1 & 0.246 & 0.476 & \\
\hline & 2 & 0.262 & 0.438 & 0.217 \\
\hline \multirow[t]{2}{*}{$\mathrm{OI} / \mathrm{A}$} & 1 & 0.002 & 0.039 & \\
\hline & 2 & 0.027 & 0.011 & 0.030 \\
\hline \multirow[t]{2}{*}{$\mathrm{OI} / \mathrm{S}$} & 1 & 0.035 & 0.210 & \\
\hline & 2 & 0.036 & 0.206 & 0.007 \\
\hline \multirow[t]{2}{*}{$\mathrm{OI} / \mathrm{E}$} & 1 & 0.062 & 0.253 & \\
\hline & 2 & 0.066 & 0.248 & 16.748 \\
\hline \multirow[t]{2}{*}{ OPEXP/S } & 1 & 0.011 & 0.101 & \\
\hline & 2 & 0.019 & 0.101 & 0.027 \\
\hline \multirow[t]{2}{*}{$\mathrm{COG} / \mathrm{S}$} & 1 & 0.022 & -0.146 & \\
\hline & 2 & 0.100 & -0.207 & 0.306 \\
\hline \multirow[t]{2}{*}{$\mathrm{SGA} / \mathrm{S}$} & 1 & 0.007 & 0.081 & \\
\hline & 2 & 0.022 & 0.062 & -0.042 \\
\hline \multicolumn{5}{|l|}{2013} \\
\hline & $\underline{\text { Model }}$ & $\underline{\text { R Square Change }}$ & $\underline{2012}$ Financial Performance & $\frac{\text { Dummy }}{\text { Variable }}$ \\
\hline \multirow{2}{*}{$\mathrm{ROA}$} & 1 & 0.135 & 0.406 & \\
\hline & 2 & 0.166 & 0.343 & 0.243 \\
\hline \multirow[t]{2}{*}{ ROS } & 1 & 0.155 & 0.416 & \\
\hline & 2 & 0.178 & 0.370 & 0.276 \\
\hline
\end{tabular}

Vol. 19, No. 3 
Information technology capability and firm performance in the era of Big Data analytics: Evidence from the United States

\begin{tabular}{|c|c|c|c|c|}
\hline \multirow[t]{2}{*}{$\mathrm{OI} / \mathrm{A}$} & 1 & 0.036 & 0.246 & \\
\hline & 2 & 0.051 & 0.219 & 0.030 \\
\hline \multirow[t]{2}{*}{$\mathrm{OI} / \mathrm{S}$} & 1 & 0.001 & 0.025 & \\
\hline & 2 & 0.002 & 0.024 & 0.010 \\
\hline \multirow[t]{2}{*}{$\mathrm{OI} / \mathrm{E}$} & 1 & 0.043 & 0.163 & \\
\hline & 2 & 0.049 & 0.158 & 17.018 \\
\hline \multirow[t]{2}{*}{ OPEXP/S } & 1 & 0.006 & 0.092 & \\
\hline & 2 & 0.010 & 0.086 & 0.019 \\
\hline \multirow[t]{2}{*}{$\mathrm{COG} / \mathrm{S}$} & 1 & 0.042 & 0.195 & \\
\hline & 2 & 0.071 & 0.153 & 0.182 \\
\hline \multirow[t]{2}{*}{$\mathrm{SGA} / \mathrm{S}$} & 1 & 0.079 & 0.290 & \\
\hline & 2 & 0.088 & 0.277 & -0.032 \\
\hline \multicolumn{5}{|l|}{2014} \\
\hline & Model & $\underline{\text { R Square Change }}$ & 2013 Financial Performance & $\begin{array}{l}\text { Dummy } \\
\text { Variable }\end{array}$ \\
\hline \multirow[t]{2}{*}{ ROA } & 1 & 0.083 & 0.504 & \\
\hline & 2 & 0.096 & 0.444 & 0.278 \\
\hline \multirow[t]{2}{*}{ ROS } & 1 & 0.052 & 0.261 & \\
\hline & 2 & 0.087 & 0.204 & 0.387 \\
\hline \multirow[t]{2}{*}{$\mathrm{OI} / \mathrm{A}$} & 1 & 0.002 & 0.055 & \\
\hline & 2 & 0.034 & 0.021 & 0.053 \\
\hline \multirow[t]{2}{*}{$\mathrm{OI} / \mathrm{S}$} & 1 & 0.015 & -0.182 & \\
\hline & 2 & 0.031 & -0.188 & 0.057 \\
\hline \multirow[t]{2}{*}{$\mathrm{OI} / \mathrm{E}$} & 1 & 0.000 & -0.021 & \\
\hline & 2 & 0.023 & -0.068 & 101.259 \\
\hline \multirow[t]{2}{*}{ OPEXP/S } & 1 & 0.001 & -0.029 & \\
\hline & 2 & 0.006 & -0.024 & -0.027 \\
\hline \multirow[t]{2}{*}{$\mathrm{COG} / \mathrm{S}$} & 1 & 0.030 & 0.177 & \\
\hline & 2 & 0.049 & 0.146 & 0.144 \\
\hline \multirow[t]{2}{*}{$\mathrm{SGA} / \mathrm{S}$} & 1 & 0.079 & 0.275 & \\
\hline & 2 & 0.091 & 0.261 & -0.037 \\
\hline \multicolumn{5}{|l|}{2015} \\
\hline & Model & $\underline{\text { R Square Change }}$ & $\underline{2014}$ Financial Performance & $\frac{\text { Dummy }}{\text { Variable }}$ \\
\hline \multirow[t]{2}{*}{ ROA } & 1 & 0.040 & 0.291 & \\
\hline & 2 & 0.062 & 0.248 & 0.511 \\
\hline \multirow[t]{2}{*}{ ROS } & 1 & 0.077 & 0.750 & \\
\hline & 2 & 0.094 & 0.662 & 0.726 \\
\hline \multirow[t]{2}{*}{$\mathrm{OI} / \mathrm{A}$} & 1 & 0.003 & 0.209 & \\
\hline & 2 & 0.018 & 0.127 & 0.132 \\
\hline \multirow[t]{2}{*}{$\mathrm{OI} / \mathrm{S}$} & 1 & 0.004 & 0.202 & \\
\hline & 2 & 0.023 & 0.148 & 0.195 \\
\hline \multirow[t]{2}{*}{$\mathrm{OI} / \mathrm{E}$} & 1 & 0.000 & 0.050 & \\
\hline & 2 & 0.016 & -0.008 & 260.108 \\
\hline \multirow{2}{*}{ OPEXP/S } & 1 & 0.008 & 0.274 & \\
\hline & 2 & 0.025 & 0.246 & -0.150 \\
\hline
\end{tabular}


Accounting and Management Information Systems

\begin{tabular}{|c|c|c|c|c|}
\hline \multirow[t]{2}{*}{$\overline{\mathrm{COG} / \mathrm{S}}$} & 1 & 0.007 & 0.124 & \\
\hline & 2 & 0.008 & 0.120 & 0.023 \\
\hline \multirow[t]{2}{*}{$\mathrm{SGA} / \mathrm{S}$} & 1 & 0.007 & 0.088 & \\
\hline & 2 & 0.037 & 0.061 & -0.062 \\
\hline \multicolumn{5}{|l|}{2016} \\
\hline & $\underline{\text { Model }}$ & $\underline{\text { R Square Change }}$ & $\underline{2015}$ Financial Performance & $\frac{\text { Dummy }}{\text { Variable }}$ \\
\hline \multirow[t]{2}{*}{$\overline{\mathrm{ROA}}$} & 1 & 0.191 & 0.496 & \\
\hline & 2 & 0.199 & 0.478 & 0.328 \\
\hline \multirow[t]{2}{*}{ ROS } & 1 & 0.453 & 1.997 & \\
\hline & 2 & 0.453 & 2.003 & -0.166 \\
\hline \multirow[t]{2}{*}{$\mathrm{OI} / \mathrm{A}$} & 1 & 0.064 & 0.055 & \\
\hline & 2 & 0.079 & 0.052 & 0.029 \\
\hline \multirow[t]{2}{*}{$\mathrm{OI} / \mathrm{S}$} & 1 & 0.093 & 0.155 & \\
\hline & 2 & 0.107 & 0.146 & 0.084 \\
\hline \multirow[t]{2}{*}{$\mathrm{OI} / \mathrm{E}$} & 1 & 0.094 & 0.046 & \\
\hline & 2 & 0.119 & 0.043 & 50.482 \\
\hline \multirow[t]{2}{*}{ OPEXP/S } & 1 & 0.062 & 0.154 & \\
\hline & 2 & 0.070 & 0.146 & -0.064 \\
\hline \multirow{2}{*}{$\mathrm{COG} / \mathrm{S}$} & 1 & 0.076 & 0.187 & \\
\hline & 2 & 0.093 & 0.184 & 0.129 \\
\hline \multirow[t]{2}{*}{$\mathrm{SGA} / \mathrm{S}$} & 1 & 0.212 & 1.014 & \\
\hline & 2 & 0.215 & 0.990 & -0.045 \\
\hline \multicolumn{5}{|l|}{2017} \\
\hline & $\underline{\text { Model }}$ & $\underline{\text { R Square Change }}$ & $\underline{2016}$ Financial Performance & $\frac{\text { Dummy }}{\text { Variable }}$ \\
\hline \multirow{2}{*}{$\overline{\mathrm{ROA}}$} & 1 & 0.039 & 0.056 & \\
\hline & 2 & 0.087 & 0.045 & 0.239 \\
\hline \multirow[t]{2}{*}{ ROS } & 1 & 0.012 & 0.013 & \\
\hline & 2 & 0.067 & 0.010 & 0.449 \\
\hline \multirow[t]{2}{*}{$\mathrm{OI} / \mathrm{A}$} & 1 & 0.094 & 0.216 & \\
\hline & 2 & 0.101 & 0.207 & 0.013 \\
\hline \multirow[t]{2}{*}{$\mathrm{OI} / \mathrm{S}$} & 1 & 0.019 & 0.056 & \\
\hline & 2 & 0.028 & 0.050 & 0.028 \\
\hline \multirow[t]{2}{*}{$\mathrm{OI} / \mathrm{E}$} & 1 & 0.010 & 0.053 & \\
\hline & 2 & 0.033 & 0.037 & 26.670 \\
\hline \multirow[t]{2}{*}{ OPEXP/S } & 1 & 0.014 & 0.050 & \\
\hline & 2 & 0.016 & 0.048 & -0.011 \\
\hline \multirow[t]{2}{*}{$\mathrm{COG} / \mathrm{S}$} & 1 & 0.049 & 0.202 & \\
\hline & 2 & 0.057 & 0.191 & 0.082 \\
\hline \multirow{2}{*}{$\mathrm{SGA} / \mathrm{S}$} & 1 & 0.026 & 0.071 & \\
\hline & 2 & 0.040 & 0.063 & -0.041 \\
\hline
\end{tabular}

Vol. 19, No. 3 
Table 8. Summary of hypotheses tests

\begin{tabular}{|c|c|c|}
\hline & Hypothesis & Results \\
\hline H1 & $\begin{array}{l}\text { Firms that had superior IT capabilities in the } 2010 \text { s are associated } \\
\text { with higher average profit ratios than those of control firms. }\end{array}$ & Supported \\
\hline $\mathrm{H} 2$ & $\begin{array}{l}\text { Firms that had superior IT capabilities in the } 2010 \text { s are associated } \\
\text { with lower average cost ratios than those of control firms. }\end{array}$ & $\begin{array}{l}\text { Partially } \\
\text { Supported }\end{array}$ \\
\hline H3 & $\begin{array}{l}\text { Firms that had superior IT capabilities in the } 2010 \text { s are associated } \\
\text { with higher average profit ratios than those of control firms in all } \\
\text { subsequent years. }\end{array}$ & Supported \\
\hline $\mathrm{H} 4$ & $\begin{array}{l}\text { Firms that had superior IT capabilities in the } 2010 \text { s are associated } \\
\text { with lower average cost ratios than those of control firms in all } \\
\text { subsequent years. }\end{array}$ & $\begin{array}{l}\text { Partially } \\
\text { Supported }\end{array}$ \\
\hline H5 & $\begin{array}{l}\text { Firms that had superior IT capabilities in the } 2010 \text { s are associated } \\
\text { with higher average profit ratios than those of control firms after } \\
\text { adjustment for prior financial performance. }\end{array}$ & $\begin{array}{l}\text { Not } \\
\text { Supported }\end{array}$ \\
\hline H6 & $\begin{array}{l}\text { Firms that had superior IT capabilities in the } 2010 \text { s are associated } \\
\text { with lower average cost ratios than those of control firms after } \\
\text { adjustment for prior financial performance. }\end{array}$ & $\begin{array}{c}\text { Not } \\
\text { Supported }\end{array}$ \\
\hline H7 & $\begin{array}{l}\text { After adjustment for previous financial performance, firms that } \\
\text { had superior IT capabilities in the } 2010 \text { s are associated with } \\
\text { higher average profit ratios than those of control firms in the } \\
\text { subsequent years. }\end{array}$ & $\begin{array}{c}\text { Not } \\
\text { Supported }\end{array}$ \\
\hline H8 & $\begin{array}{l}\text { After adjustment for previous financial performance, firms that } \\
\text { had superior IT capabilities in the } 2010 \text { s are associated with lower } \\
\text { average cost ratios than those of control firms in the subsequent } \\
\text { years. }\end{array}$ & $\begin{array}{l}\text { Not } \\
\text { Supported }\end{array}$ \\
\hline
\end{tabular}

\section{Discussion and conclusions}

\subsection{Conclusions}

Despite insufficient evidence on the subject, we are motivated by the growing worldwide attention to whether a firm's IT capability affects its financial performance in the era of BDA. We investigated this issue in the context of the United States by (1) selecting IT leaders and corresponding control groups from IW 500 and comparing their profit ratios and cost ratios from 2010 through 2017 and (2) adjusting for the financial halo effects to remove the effects from the previous years' financial performance on the following years' financial performance. The findings indicate that although IT leaders did show and sustain higher profit ratios than control groups before adjusting for the financial halo effects, such a relationship no longer exists after the adjustment. Since the 2010s, both academic and business communities have become increasingly interested in big data-enabled business value 
(McAfee \& Brynjolfsson, 2012; Wamba et al. 2015), and the storage, computation, analysis, visualization, and integration of big data relies heavily on a firm's IT capability.

Therefore, this research serves as a future reference for the business and academic communities to consider a BDA strategy as part of IT capability to positively influence business performance. It augments Bharadwaj (2000), Santhanam and Hartono (2003), and Chae (2014), by taking the BDA factor into consideration with the latest data from 2010 through 2017 . Nevertheless, the results of the study should be cautiously interpreted because of the existence of certain limitations and issues, such as the categorization of IT leaders and control groups that needs the attention of future researchers.

This research has opened a Pandora's box filled with questions worthy of investigation by future researchers. For example, alternate methodologies that are more robust and reliable should be developed to define firms with superior IT capabilities. Moreover, other valid variables and constructs that could possibly influence the link between IT capability and financial performance should be identified and incorporated in future studies. In addition, it could be insightful to examine the relationship at sublevels to consider the different organizational characteristics such as industry type and size. Future research is needed, but is not limited to the above perspectives, and we hope that this study can be an inspiration for future studies that elaborate its findings.

\subsection{Reliability and validity}

This study follows the methodology and instructions from a model paper published in MIS Quarterly, a leading journal of management information systems (Chae et al., 2014). Although our data were extracted from different years, the results of the hypotheses tests are similar to those of the model paper. As discussed earlier, the model paper also found no link between IT capability and business performance after adjusting for previous years' firm performance. Therefore, this research is reliable. In terms of validity, the results of this study can only be generalized to US-listed firms. First, IW 500 only selects firms from the United States. In addition, 13 firms acknowledged as IT leaders by IW 500 were excluded because they were not listed companies, which resulted in their financial data being inaccessible and not included in this study. A further 207 firms' financial data were not fully available in Compustat's database (i.e., missing values in certain years for certain variables), and thus were not considered. The firms eliminated due to the reasons given above could have made a significant difference to this study's results, but it is not feasible to discuss their impacts under the current conditions. 


\subsection{Limitations}

Although our findings indicate that strong IT capability does not necessarily result in its superior and sustained business performance in the BDA era, it is premature to make such a claim. More research is needed to understand the mechanisms of IT capability and business performance in the BDA era, and we highlight the following limitations to help understand the results critically. To systematically assess the limitations of this research, first the sample selection should be investigated. As shown in Table 3, the average sales and assets of the IT leaders' group were almost twice as much as those of the control group. Therefore, firm size, dissimilar IT budgets, or even slight accounting maneuvers in depreciation and amortization might have affected their net income and therefore, their financial measurements (Chae et al., 2014). Second, errors could have crept in during the sample selection process. Although choosing samples from IW 500 has advantages such as quality respondents and a high response rate, IW 500's frequent and inevitable changes in the selection process have posed challenges for researchers who pay attention to the benchmarking criteria. In fact, since IW 500 published its first list in 1989, its selection criteria for inclusion have continuously changed and the process is not consistent (Chae et al., 2014). Moreover, the firm selection procedure adopts a binary measure that identifies firms as leaders or not leaders. Such a measurement method makes the evaluation of the influence of incremental improvements in IT capability on firm performance impossible (Santanam \& Hartnono, 2003).

\subsection{Theoretical contributions}

This research adds value to two aspects of the IT literature. First, it attempts to further the understanding of how a firm's IT capability relates to its business performance by introducing the impact of BDA since the 2010s. Second, it extends previous studies with fresh data from the 2010s. The previous research that discussed the relationship between a firm's IT capability and its business performance, was conducted with data from the early 1990s and 2000s; it is doubtful that those findings still hold true after decades of dramatic change in the business use of technologies, especially the growing popularity and application of big data analytics as part of business strategy.

\subsection{Discussion}

This research attempts to answer a vital question: does the relationship between a firm's IT capability and its business performance still hold true after experiencing a large technology advancement such as BDA? Both positive links and no positive links between IT capability and organizational performance have been found in previous studies (Bharadwaj, 2000; Chae et al., 2014; Santhanam \& Hartono, 2003). However, as this past research uses data from the early 1990s and 2000s, updates on our understanding are necessary. Therefore, this study replicates, extends, and 
updates the three previous studies with the data from the 2010s to investigate how the advantage of being an IT leader has changed since the early 1990s. The significance of this method is that it demonstrates that IS researchers generally underutilize replications and updates, which are important elements of scientific studies (Berthon et al. 2002).

The expected results are that IT leaders from 2010 through 2013 were associated with higher profit ratios and that they also sustained this from 2014 through 2017. However, IT leaders did not necessarily achieve lower cost ratios from 2010 through 2017, which was unexpected. Moreover, after adjusting for the financial halo effect, which aimed to remove the effects of the previous years' financial performance in the following years, IT leaders were neither associated with superior business performance nor sustained superior business performance.

To analyze both the expected and unexpected results, it is necessary to understand the role of IT capability and BDA in business performance since the 2010s. As discussed, IT capability plays a significant and positive role in BDA adoption and application. Due to the hypercompetitive nature of modern business environments, firms 'attention has been drawn to utilize IT capability-enabled information to develop organizational capabilities (Chakravarty et al., 2013). The application of BDA particularly plays an important role in assisting operational and strategic decision making, and thus enhances organizational performance (Kiron et al., 2014). Insights derived from BDA can improve real-time business process monitoring and measurement, enhance quality control (Waller and Fawcett, 2013; Davenport et al., 2012), reinforce customer relationships, manage operational risks, elevate operational efficiency and effectiveness, and facilitate product or service delivery (Kiron, 2013; Zelbst et al., 2011). Therefore, the results of $\mathrm{H} 1$ and H3, which show that IT leaders have higher profit ratios and that such advantages are sustained, can be validated.

However, transforming the advantages of IT capability and BDA into business value is challenging. The challenges start from the senior level, where top-level decision makers need to embrace evidence-based decision making and encourage all organizational members to redefine its understanding of "judgment" (McAfee $\&$ Brynjolfsson, 2012). In addition, readiness factors and organizational design are critical factors for IT utilization and therefore, developing IT capability may not necessarily enhance business performance (Hong \& Kim, 2002; Dezdar \& Sulaiman, 2010). To sum up, utilizing BDA (such as data sourcing, access, integration, delivery, advanced analytics capacity and capabilities, and human resources) and organizational factors (in terms of top management support, BDA strategy, financial resources, and people engagement) can both inhibit and facilitate the effective utilization of BDA in operations. Thus, the benefits of BDA utilization do not translate into business value quickly and easily (Popovič et al., 2014). This study speculates that the high costs associated with BDA adoption and 
application are also reflected in a firm's cost ratios, which explains the results of $\mathrm{H} 2$ and $\mathrm{H} 4$.

None of the hypotheses from H5 through $\mathrm{H} 8$ are supported, which is interesting because the regression conducted in this study can be regarded as more conservative and rigorous than the pair-wise comparison, as the Wilcoxon signed-rank test (Santhanam \& Hartono, 2003) was adopted. Although the results are surprising, similar patterns were also found in previous studies (Chae et al., 2014; Santhanam \& Hartono, 2003). These researchers also found that the significant effect of IT capability on organizational performance presented via a pair-wise comparison became less apparent when it was measured using regression analysis.

\section{References}

Agarwal, R. and Dhar, V. (2014) Big data, data science, and analytics: The opportunity and challenge for IS research. Information Systems Research, vol. 25 : $443-448$

Agrawal, K.P. (2015) "Investigating the determinants of Big Data Analytics (BDA) adoption in emerging economies", Academy of Management Proceedings, vol. 2015, no. 1: 11290

Akter, S. \& Wamba, S.F. (2016) "Big data analytics in E-commerce: a systematic review and agenda for future research", Electronic Markets, vol. 26, no. 2: 173-194.

Berthon, P., Pitt, L., Ewing, M. \& Carr, C.L. (2002) "Potential research space in MIS: A framework for envisioning and evaluating research replication, extension, and generation", Information Systems Research, Vol. 13, no.4: 416-427.

Bharadwaj, A.S. (2000) "A resource-based perspective on information technology capability and firm performance: an empirical investigation", MIS Quarterly, vol. 24, no. 1:169-196.

Brown, B. \& Perry, S. (1994) "Removing the financial performance halo from Fortune's "most admired" companies", Academy of Management Journal, vol. 37, no. 5: 1347-1359.

Carr, N. (2003) "IT doesn't matter", Educause Review, vol. 38: 24-38

Chae, H.C., Koh, C.E. \& Prybutok, V.R. (2014) "Information technology capability and firm performance: contradictory findings and their possible causes", MIS Quarterly, vol. 38, no.1: 305-326

Chakravarty, A., Grewal, R. \& Sambamurthy, V. (2013) "Information technology competencies, organizational agility, and firm performance: Enabling and facilitating roles", Information Systems Research, vol. 24, no. 4: 976-997

Chan, Y.E. (2000) "IT value: The great divide between qualitative and quantitative and individual and organizational measures", Journal of Management Information Systems, vol. 26, no.4: 225-261 
Chullen, A., Kaltenbrunner, H. \& Schwetzler, B. (2015) "Does consistency improve accuracy in multiple - based valuation", Journal of Business Economics, vol. 85 , no. $6: 635-662$

Clemons, E.K. \& Row, M.C. (1991) "Sustaining IT advantage: The role of structural differences", MIS Quarterly, vol. 15, no. 3: 275-292

Clemons, E.K. (1986) "Information systems for sustainable competitive advantage", Information \& Management, vol. 11, no.3: 131-136

Davenport, T.H. (2006) “Competing on analytics”, Harvard Business Review, vol. 84, no. 1: 98

Davenport, T.H., Barth, P. \& Bean, R. (2012) "How 'big data' is different", MIT Sloan Management Review, vol. 54, no. 1: 22-24

Davern, M.J. \& Kauffman, R.J. (2000) "Discovering potential and realizing value from information technology investments", Journal of Management Information Systems, vol. 16, no.4: 121-143

Dehning, B. \& Richardson, V.J. (2002) "Returns on investments in information technology: A research synthesis", Journal of Information Systems, vol. 16, no. $1: 7-30$

Dezdar, S. \& Ainin, S. (2011) "The influence of organizational factors on successful ERP implementation", Management Decision, vol. 49, no. 6: 911-926

Enache, L. \& Anup, S. (2018) "Should intangible investments be reported separately or commingled with operating expenses? New evidence", Management Science, vol. 64, no. 7: 3446-3468

Fahy, J. \& Hooley, G. (2002) "Sustainable competitive advantage in electronic business: towards a contingency perspective on the resource-based view", Journal of Strategic Marketing, vol. 10, no. 4: 241-253

Gandomi, A. \& Haider, M. (2015) "Beyond the hype: Big data concepts, methods, and analytics", International Journal of Information Management, vol. 35, no. 2: $137-144$

Grant, R.M. (1991) "The resource-based theory of competitive advantage: implications for strategy formulation", California Management Review, vol. 33 , no. 3: $114-135$

Grover, V., Chiang, R.H., Liang, T.P. \& Zhang, D. (2018) "Creating strategic business value from big data analytics: A research framework", Journal of Management Information Systems, vol. 35, no.2: 388-423

Hitt, L.M. \& Brynjolfsson, E. (1996) "Productivity, business profitability, and consumer surplus: three different measures of information technology value", MIS Quarterly, vol. 20, no. 2: 121-142

Hong, K.K. \& Kim, Y.G. (2002) "The critical success factors for ERP implementation: an organizational fit perspective", Information \& Management, vol. 40, no. 1: 25-40

Iqbal, R., Doctor, F., More, B., Mahmud, S. \& Yousuf, U. (2020) "Big data analytics: computational intelligence techniques and application areas", Technological Forecasting and Social Change, vol. 153: 119-253 
Kanodia, C., and Haresh, S. (2016) "A real effects perspective to accounting measurement and disclosure: Implications and insights for future research", Journal of Accounting Research, vol. 54, no. 2: 623-676

Kiron, D., Prentice, P.K. \& Ferguson, R.B. (2014) "Raising the bar with analytics", MIT Sloan Management Review, vol. 55, no. 2: 29

Kohli, R. \& Devaraj, S. (2003) "Measuring information technology payoff: A meta-analysis of structural variables in firm-level empirical research", Information Systems Research, vol. 14, no. 2: 127-145

LaValle, S., Lesser, E., Shockley, R., Hopkins, M.S. \& Kruschwitz, N. (2011) "Big data, analytics and the path from insights to value", MIT Sloan Management Review, vol. 52, no. 2: 21-32

Mahmood, M.A., Mann, G.J. \& Zwass, V. (2000) "Impacts of information technology investment on organizational performance", Journal of Management Information Systems, vol. 16, no. 4: 3-10

Marr, B., (2016) Big data in practice: How 45 successful companies used big data analytics to deliver extraordinary results, John Wiley \& Sons.

Mata, F.J., Fuerst, W.L. \& Barney, J.B. (1995) "Information technology and sustained competitive advantage: A resource-based analysis", MIS Quarterly, vol. 19, no. 4: 487-505

McAfee, A., Brynjolfsson, E., Davenport, T.H., Patil, D.J. \& Barton, D. (2012) "Big data: the management revolution", Harvard Business Review, vol. 90, no. 10: 60-68

Melville, N., Kraemer, K. \& Gurbaxani, V. (2004) "Information technology and organizational performance: An integrative model of IT business value", MIS Quarterly, vol. 28, no. 2: 283-322

Mikalef, P., Pappas, I.O., Krogstie, J. \& Giannakos, M. (2018) "Big data analytics capabilities: a systematic literature review and research agenda", Information Systems and e-Business Management, vol. 16, no. 3: 547-578

Mithas, S., Ramasubbu, N. \& Sambamurthy, V. (2011) "How information management capability influences firm performance", MIS Quarterly, vol. 35 , no. $1: 237$

Popovič, A., Hackney, R., Coelho, P.S. \& Jaklič, J. (2012) “Towards business intelligence systems success: Effects of maturity and culture on analytical decision making", Decision Support Systems, vol. 54, no. 1: 729-739

Popovič, A., Hackney, R., Coelho, P.S. and Jaklič, J. (2014) "How information-sharing values influence the use of information systems: An investigation in the business intelligence systems context", The Journal of Strategic Information Systems, vol. 23, no. 4: 270-283

Popovič, A., Hackney, R., Tassabehji, R. \& Castelli, M. (2018) “The impact of big data analytics on firms' high value business performance", Information Systems Frontiers, vol. 20, no. 2: 209-222

Powell, T.C. \& Dent-Micallef, A. (1997) "Information technology as competitive advantage: The role of human, business, and technology resources", Strategic Management Journal, vol. 18, no. 5: 375-405 
Ray, G., Muhanna, W.A. \& Barney, J.B. (2005) "Information technology and the performance of the customer service process: A resource-based analysis", MIS Quarterly, vol. 29, no.4: 625-652

Salehan, M. \& Kim, D.J. (2016) "Predicting the performance of online consumer reviews: A sentiment mining approach to big data analytics", Decision Support Systems, vol. 81, no. C: 30-40

Santhanam, R. \& Hartono, E. (2003) "Issues in linking information technology capability to firm performance", MIS Quarterly, vo. 27, no. 1: 125-153

Singh, S.K. \& El-Kassar, A.N. (2019) "Role of big data analytics in developing sustainable capabilities", Journal of Cleaner Production, vol. 213: 1264-1273

Stoel, M. D. \&Muhanna W. A. (2009) "IT capabilities and firm performance: A contingency analysis of the role of industry and IT capability type", Information \& Management, vol. 46, no. 3:181

Straub, D.W. \& Watson, R.T. (2001) "Research commentary: Transformational issues in researching IS and net-enabled organizations", Information Systems Research, vol. 12, no. 4: 337-345

Wade, M. \& Hulland, J. (2004) "The resource-based view and information systems research: Review, extension, and suggestions for future research", MIS Quarterly, vol. 28, no.1: 107-142

Waller, M.A. \& Fawcett, S.E. (2013) "Data science, predictive analytics, and big data: a revolution that will transform supply chain design and management", Journal of Business Logistics, vol. 34, no. 2: 77-84

Wamba, S.F., Akter, S., Edwards, A., Chopin, G. \& Gnanzou, D. (2015) "How 'big data' can make big impact: Findings from a systematic review and a longitudinal case study", International Journal of Production Economics, vol. 165, no. C: $234-246$

Wamba, S.F., Gunasekaran, A., Akter, S., Ren, S.J.F., Dubey, R. \& Childe, S.J. (2017) "Big data analytics and firm performance: Effects of dynamic capabilities", Journal of Business Research, vol. 70: 356-365.

Wang, P. (2007) "Chasing the hottest IT: Effects of information technology fashion on organizations", MIS Quarterly, vol. 34, no. 1: 1-7

White, M. (2012) "Digital workplaces: Vision and reality", Business Information Review, vol. 29, no. 4: 205-214.

Wixom, B.H. \& Todd, P.A. (2005) "A theoretical integration of user satisfaction and technology acceptance", Information Systems Research, vol. 16, no. 1: 85-102

Wüstemann, Jens, \& Wüstemann, S. (2010) "Why consistency of accounting standards matters: A contribution to the rules-versus-principles debate in financial reporting", Abacus, vol. 46, no. 1: 1-27

Zhu, K., Kraemer, K.L. \& Xu, S. (2006) "The process of innovation assimilation by firms in different countries: a technology diffusion perspective on e-business", Management Science, vol. 52, no. 10: 1557-1576 